\title{
Alternative Lenses for Viewing How China Has Built its Accounting and Auditing Profession
}

\author{
Richard MACVE \\ London School of Economics \\ R.Macve@lse.ac.uk \\ Running Head: Alternative lenses for viewing China's accounting and auditing profession \\ Forthcoming in Journal of Accounting in Emerging Economies: DOI \\ (10.1108/JAEE-01-2019-0029) \\ This version 29.02.20 Accepted 6.7.20 \\ Acknowledgements: I am most grateful to Dr Shuwen Deng for her collaboration in designing, carrying \\ out and interpreting the interviews that enabled us to undertake the empirical investigations from which this \\ theoretically focussed analysis is derived (Macve, 2020). We are also grateful for the comments of discussants \\ and participants at the various conferences and seminars in US, UK, and China where we have made \\ presentations of earlier versions of the paper, and in particular at the AAEE Conference, Essex Business School, \\ June 2018. Particular thanks to JAEE's anonymous reviewers.
}

(C) Richard Macve, 2020

JAEE-01-2019-0029. Submitted: 311 2019. Revised: 2922020 Accepted: 672020 


\title{
Alternative Lenses for Viewing How China Has Built its Accounting and Auditing Profession
}

\begin{abstract}
Purpose - The paper reviews some theoretical approaches that have been adopted for understanding the drivers and achievements of the Chinese professional project and the challenges it faces for the future, as a complement and a contrast to previous histories of China and to studies of other developing economies.

Design - Based mainly on evaluating the information as obtained from the interviews in mainland China, in Hong Kong and in London reported by Macve (2020), complemented by other published histories.

Findings - China remains a paradox. Since the 'reform and open' policy began in 1978 it has been transformed from one of the poorest countries to one of the economically most powerful in just some 40 years. However it remains (per capita) a 'developing country' / 'emerging economy' and ideologically a Communist country. While the accounting profession in the USA and UK has developed 'from the bottom up' over more than a century and a half, the Chinese profession has effectively been created 'from the top down' in under 25 years. The paper outlines alternative theorizations of the the major stages in this achievement, in the context of the continuing rapid growth of China's economy and its stock markets, and of the overseas expansion of its manufacturing and increasingly service-oriented base.

Research limitations/implications - Space has restricted the analysis here to a general overview. Application of Gramsci's hegemony theory is argued to be inappropriate in the context of understanding China's professional project. Instead, this study is framed within the neoinstitutional theory of 'linked ecologies' originally developed to examine 'Western' developments and extended to the emergence of glocalization, while offering a comparison with related theorization of Russia's post-Communist development. Further theoretical development outside the Western neo-liberal context is called for.

Originality/value - The paper demonstrates how accounting and auditing's development in this globally significant context has differed from that in other developing and transitional economies, reflecting in particular the proactive agency of the state. Given China's economic power, fuller understanding of the interrelated factors shaping its development is important for understanding the likely future shaping of the worldwide profession.
\end{abstract}

Keywords: Chinese auditing profession; Chinese audit regulation; glocalization; hegemony; linked ecologies

Paper type Research paper 


\section{Alternative Lenses for Viewing How China Has Built its Accounting and Auditing Profession}

\section{Introduction}

It is under 25 years since the Chinese Institute of Certified Public Accountants (CICPA) was finally established in its present form in 1995. Rapid growth has resulted in its membership already reaching over 250,000 CPAs. 1 While the profession in the USA and UK has developed 'from the bottom up' over more than a century and a half, 2 the Chinese profession has effectively been created from scratch 'from the top down' in that short space of time.

In China the direction of development has been formal delegation from the Communist government to the new professional body which has remained 'under the guidance of the Ministry of Finance (MoF) and the Council'.3 Another arm of government, the China Securities Regulatory Commission (CSRC), which has the status of a Ministry as its head also reports directly to the Premier, also supervises the firms that audit companies listed on the huge domestic stock exchanges of Shanghai and Shenzhen (respectively the 4th and 8th largest in the world), while the Hong Kong FRC, which supervises the Hong Kong Stock Exchange (the 5th largest in the world) 4 now also has a role in monitoring the 11 mainland PRC audit firms that have been granted ' $\mathrm{H}$ ' share licenses since 2011, i.e. licenses to audit companies listed in Hong Kong.

However although China is now the second largest economy in the world,5 paradoxically it is still a 'developing country' / 'emerging economy'. As measured by per capita income it remains 73 rd globally.6

\footnotetext{
${ }^{1}$ http://www.cicpa.org.cn/introcicpa/about/201407/t20140708_45449.html (accessed 23.2.2020).

${ }^{2}$ After about 130 years growth the US AICPA has about 430,000 members. After 140 years' growth the UK ICAEW has about 153,000 members; and after over 115 years growth the UK-based ACCA has about 220,000 members. http://www.aicpa.or/Pages/default.aspx ; http://www.icaew.com/en/about-icaew/who-we-are ; https://www.accaglobal.com/uk/en/about-us/our-history.html\#d-1910 (all accessed 23.2.2020).

${ }^{3}$ The State Council is the chief administrative authority of the PRC, chaired by the Premier.

${ }^{4} \mathrm{https}$ ://www.valuewalk.com/2019/02/top-10-largest-stock-exchanges/ (accessed 23.2.2020).

${ }^{5}$ First if measured in purchasing power parity terms (ppp): http://statisticstimes.com/economy/projected-world-
} 
In spite of their different historical pathways the modern profession in different countries globally exhibits increasing governmental control. For example, in both the UK and the US regulation of the profession has increasingly moved (largely in response to successive accounting and auditing scandals) from self-regulation to oversight by legally mandated bodies: in the UK, the Financial Reporting Council (FRC) (now itself due to be replaced by a stronger body — the Audit, Reporting and Governance Authority) 7 and in the US the Public Company Accounting Oversight Board (PCAOB). This increasing concentration of regulation has led internationally both to 'regulatory black holes' (Gillis, 2014a) where company arrangements may be structured to avoid regulation in any jurisdiction; and to conflicts between regulators over their respective rights of inspection within different jurisdictions (as with recent disputes over the PCAOB's power to inspect audit working papers relating to audits of Chinese companies). 8

But, despite the increasing day-to-day surface similarities, and although China's economy is no longer wholly state-planned, the underlying political philosophies remain very different as between Western 'capitalism' and China's 'socialist market economy'9 (its unique combination of market autonomy and techno-scientific administrative regulation under the Communist Party's (CPC) overall direction). As Macve (2020) argues: '[E]ven though it may appear quite surprising to "Western" eyes that have become accustomed to the neoliberal world order of the Washington consensus that underpins the current international dominance of the Big 4,...accounting and audit firms in China remain subject, probably to an almost unique degree, to direction by a government that has a vision and a strategic plan for the role it wants them to play domestically and internationally (and in particular the members

gdp-ranking.php (accessed 14.2.2020).

6 Report for Selected Countries and Subjects. www.imf.org (accessed 23.2.2020).

${ }^{7} \mathrm{https}: / / \mathrm{www}$.gov.uk/government/news/independent-review-of-the-financial-reporting-council-frc-launchesreport (accessed 23.2.2020)

8 See e.g. http://www.chinaaccountingblog.com/weblog/archives/07-2017.html (accessed 23.2.2020).

${ }^{9}$ shèhuìzhǔyì shìchăng jīngjì [社会主义市场经济]. 
of the second-tier international networks and the leading stand-alone firms). There are no such strategies in the US or UK. Given the sheer size of the firms in China (again almost unique and which is still rapidly growing) it seems inevitable that this will alter the balance of the structure, management and culture of the current leading firms worldwide and may also alter the structure and processes of international regulation and standard setting. Indeed, the government has a longstanding aim...for a recognizably "Chinese" firm or firms to join the current international leaders and become a "Big N" firm'.

This paper explores how researchers have characterised the rapid development of the Chinese profession that has been achieved in the period following the era of Chairman Mao and how the factors that have been driving the growing reputation of China's audit firms may now be expected to influence their future global status, in the context of the continuing rapid growth of China's economy and its stock markets, and of the overseas expansion of its manufacturing and increasingly service-oriented base. It seeks to challenge previously published histories and analyses and explore what is a more appropriate lens through which to view the successes of the Chinese professional project as an example of 'glocalization' 10 and the challenges it faces for the future.

Gillis (2014a) pp. 9, 268 cites several previous studies of the growth of the accounting profession and of the role of the Big 4 and their relationship with the domestic profession and with homegrown firms in various countries. These have included Greece (Ballas 1998; Caramanis 1999, 2002, 2005; cf. Macve 1997), Belgium (De Beelde, 2002) and France (De Beelde et al., 2009; Ramirez, 2010). But EU countries have longer continuous (albeit contested) 'neoliberal' traditions including both audit of 'private businesses' and liberal education, whereas these have only recently resurfaced (in different ways) in transitional particularizing tendencies." See e.g. Crawford et al., 2015; Baskerville and Grossi, 2019. 
economies such as Russia and China (cf. Harrison \& Ma, 2013; Brandt et al. 2014). And the sheer scale of China's current economy now, and its inherited non-Western traditions, make direct comparisons with the past experiences of smaller countries in facing globalising forces of more limited significance.

Chua and Poullaos (e.g. 2002) look at the varied impact of the British inheritance in 'the old Commonwealth' while Ferguson et al. (2014) focus on the factors producing the growth of Australia's large audit firms before they too became part of the Big 4 and Baskerville \& Hay (2010) look at New Zealand. By contrast, China does not have the competing professional bodies that are a feature of these countries (as of the UK itself) and whose rivalry and power-relationships need to be analysed (e.g. Richardson, 1989).11 In the Chinese context the colonial legacy is restricted to Hong Kong (which was returned to China in 1997) where KPMG established a partnership in 1945 to service its client The Hong Kong and Shanghai Bank (now HSBC) (Lewis, 2005) and the local professional body (now the HKICPA) was first established in 1973.12

Karube and Fukukawa (2013) examine the growth through mergers of Japan's four largest firms (all of whom are now linked in different ways to the international Big 4). But Western influence has always been stronger in Japan than in China since the end of the 19 th century and particularly US influence since the end of WWII (cf. Brandt et al., 2014; Bickers, 2017).

All of the above are now 'developed' countries: studies of those that are still emerging ('developing countries' [DCs] or 'emerging economies' [EEs]) have focused on issues that include the role of transnational institutions, such as the importation (at least in name) of the international auditing and accounting standards set by IFAC and IASB (often at the behest of

11 However Annissette (1999; 2000) looks at Trinidad and Tobago where its Institute of Chartered Accountants is the only professional body: https://www.ifac.org/about-ifac/membership/country/trinidad-and-tobago (accessed 28.2.2020).

12 https://home.kpmg/cn/en/home/about/history.html ; https://www.hkicpa.org.hk/en/Aboutus/Organization/Overview (accessed 24.2.2020). 
the World Bank etc.); the influence of international professional accountancy bodies and the barriers to the establishment of local professional bodies; the dominance of the international Big 4 in the audit and consultancy markets; and the influence of privatizations, capital markets and the strength of regulation and state direction (e.g. Hopper et al., 2012). 13

More recently Hopper et al. (2017) 'catalogues a litany of failed or disappointing accounting reforms in DCs in the face of globalisation. Reforms are often implemented but prove irrelevant or unsuitable for local circumstances and needs, and become ceremonial, unused, or used for unintended purposes, and even be dysfunctional' (p.142). However China and its successes receive only passing mentions and the sheer scale and transformation of China's current economy now and its rapid and significant progress in the elimination of poverty, together with its inherited and continuing non-Western traditions, make direct comparisons with the past experiences of smaller DCs in facing globalising forces of limited significance.

Samsonova-Taddei \& Humphrey (2014) review the roles of professional accountancy bodies in a variety of countries while the closest comparator to the Chinese case is Mennicken's $(2008,2010)$ examination of the transition from state inspection to 'audit business' in the overthrow of Communism in Russia and of the role of the Big 4 there (cf. Samsonova, 2009). However Russia is not seen as likely potentially to become the dominant world economic power and Mennicken comments that Russia's government has played a more backstage role, while China's government, albeit remaining Communist in political ideology, has been proactive in promoting the institutions of its new 'socialist market economy' with 'Chinese characteristics'.14,15 China illustrates a unique model of glocalization. (For further details see Appendix II.)

\footnotetext{
${ }^{13}$ They also raise wider issues about public sector accounting, NGOs and social and environmental accountabilities which are beyond the scope of this paper.

${ }^{14}$ shèhuìzhǔyì shìchăng jīngjì [社会主义市场经济]

${ }^{15}$ zhōngguó tèsè [中国特色]
} 
Hegemony?

A common theme in many studies is tracing the strategies by which the Anglo-American Big 4 have achieved and retained dominance over the 'local' profession: often labelled ‘hegemony’. Gramsci’s (1935/1971) Marxist analysis of hegemony was originally developed to explain how European bourgeois capitalism had delayed the Communist revolution outside Russia mainly through the power of ideology to keep the working class identifying their own good with the good of the capitalist class. In his analysis of the developments that have occurred since the reconstruction of the private sector audit industry in China began, Gillis (2014a) employs Gramsci's analysis as his theoretical lens and argues that the local CPA firms' resistance to the power of the Big 4 represents 'counter-hegemony'. But, while it is appropriate to acknowledge (like Suddaby et al. 2007) the neo-institutional insight that the Big 4 form part of a 'globalizing capitalist class' (that also includes governments, agencies such as the World Bank, multinational corporations, international investment banks, international law firms, the WTO, the UN, and even Western universities, ideologically reinforced by a discourse of the 'international accounting and auditing standards' seen as needed for freely functioning capital markets) one does not need to see the Chinese conflicts as representing 'class-struggle' in the classic sense of overcoming working-class resistance. It was the CPC itself, as part of its strategy to lift hundreds of millions of people out of grinding poverty, that initially encouraged the entry of the (then) Big 5, through establishing joint ventures (JVs) with Chinese firms, and subsequently promoted convergence with international standards (assisted by World Bank funding and the technical assistance of Big 4 firms as consultants-Gillis, 2014a, p.218).

Moreover, the new Chinese audit firms themselves generally came from relatively high level social and educational backgrounds, having emerged from origins in the government 
and universities, while their staff and partners include former employees of Big 4 firms and, as Gillis documents (2014a, pp.211-13), the largest of them have themselves been associated at different times with one or more of the international firms (e.g. Luk, 2010). Rather there is the tendency that has been observed in many other countries, where expensive expatriate US and UK partners are gradually replaced by local personnel, and ultimately partners, as the international firms are 'localized' (cf. Cooper et al. 1998). The important issue is how fast this localization occurs and the current Chinese government policy (reflected in the 2012 'localization' regulations that require audit firms to have a majority of Chinese CPA partners and that the managing partner is a Chinese CPA) 16 appears to reflect a conviction that market forces alone will not achieve the desired outcome fast enough.

Gillis (2014a: 28) rejects this criticism as he argues that the Marxist analysis of class struggle can apply beyond the traditional 'working-class' and apparently to any differentiation of socio-economic groups or 'strata' that are pursuing conflicting interests in a context of unequal power. Certainly class struggle is not limited to the industrial working class, as Mao Zedong had to argue in the Chinese context where the downtrodden majority were still agricultural peasants. So it has also been applied to other agriculturally based economies (see e.g. the discussion in Macve (2002) of de Ste. Croix's analysis of the ancient Greek world in terms of 'class' versus Finley's in terms of 'status'). But here too the fact of ruthless exploitation seems to be central to the Marxist class definitions, which is much deeper than merely unequal access to economic rewards and to status and power.

There can be no quarrel in this context with the 'softer' definition of hegemony now quoted by Gillis (2014a: p.102) from Gilbert: 'A hegemonic project is what you get when one group in society manages to convince a number of other groups that their interests will be well served by entering into a social coalition in which the hegemonic group is the leading

16 The issues are discussed further in Macve (2020). 
partner', 17 which does not imply Gramsci's Marxist categorisation as brutal domination/exploitation. However, this definition, which seems to reflect the way other accounting researchers have deployed the concept in analyses of the State and the corporatist structures that underpin the profession (e.g. Richardson 1989; Yee, 2009, 2012) seems closer to the hegemonia (leadership status awarded through respect rather than hegemony maintained by ideological domination of the oppressed) which Reich \& Lebow (2014) argue is the world role that China has seen for itself both historically and now.18 Although Western commentators do increasingly comment on how new 'exploited' groups have emergedparticularly the evicted landless poor and migrant urban workers - within China's increasingly unequal society (e.g. Brandt et al., 2014: 108-11), nevertheless local CPAs hardly fit in that mould.

For this reason this paper rejects Gillis's (2014a) 'Marxist' argument that the Chinese development should be seen as an instance of 'Gramscian' hegemony of the Big 4 gradually being overcome by domestic resistance. A related objection applies to Yee $(2009 ; 2012)$ who employs a 'Gramscian' framework in documenting the government directed growth of the profession and the merger of the CICA and CICPA into one CICPA institute in 1995 (cf. Li, 2007, p.197).19 As Yee (2009) puts it: 'Through effectively exercising its political and ideological leadership, the state successfully mobilised the Chinese accountants in the implementation of its economic-related agenda. The paper demonstrates that the state has clearly achieved hegemony within the accounting community, and further suggests that the state-accounting profession relationship could be likened to the father-son relationship as

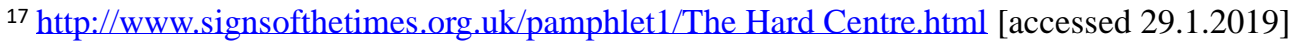

${ }^{18}$ Both are derived from the ancient Greek concept of $\dot{\eta} \gamma \varepsilon \mu o v i \alpha$. Reich and Lebow observe that Thucydides (who is quoted by Caramanis, 2002: 379) chronicles how Athens's original leadership role in the Delian League (478-404 BC) reflected a position of honour (which they label 'hegemonīa') established through the respect of its tribute-bearing allies following the defeat of Persia at the battle of Plataea. But it gradually degenerated as Athens increasingly exercised dominant hegemony, including by force, over what it came to regard as its 'empire'. 19 For a contemporaneous analysis of the issues underlying the merger see Liu, 1993; Macve and Liu, 1995.
} 
encompassed within the Confucian notion of wu lun.'20 However, it is surely anomalous to apply Gramsci's analysis of the underlying forces at work within Western 'democratic' states to what remains, ideologically if not always in practice (e.g. Pei, 2016), an authoritarian Marxist-Leninist state.21

Ezzamel, Spence and Zhu (2020) seek to deploy Bourdieu's (e.g. 2014) theory of the state and the roles of 'material' and 'symbolic' power to explore the habitus of Chinese CPAs. Again it is unclear how Bourdieu's analysis of the underlying forces at work within Western 'democratic' states can be usefully applied to a totalitarian state such as China where both action and ways of thinking have long been visibly dominated at all social and political levels by the CPC (see e.g. Feuchtwang \& Steinmüller, 2017).

Methodologically therefore the theorisation adopted here of the Chinese developments is more in line with the neo-institutionalism that explores the 'linked ecologies' within which developments are driven nationally and internationally and recognises the contradictions within the modern world's expanding 'glocalization' (e.g. Suddaby \& Muzio, 2015; Crawford et al., 2015; Baskerville and Grossi, 2019) which shapes the interplay between global and local 'institutional logics' (Thornton et al. 2012).22

\section{'Linked ecologies'}

${ }^{20}$ wǔ lún [五伦].

${ }^{21}$ E.g. http://english.people.com.cn/98666/100882/ (accessed 29.2.20). The highlight of President Xi Jinping's visit to Cuba was his meeting with Fidel Castro (China Daily, 24.07.2014). However, the ever increasing emphasis on 'marketisation' of the Chinese economy (viewed ideplogically as a necessary stage on the road to perfect socialism), while the West has retreated towards more government regulation and even ownership (especially of major financial institutions) since the 2008 financial crisis, has brought ever greater convergence between the two economic systems.

22 As its economic power has escalated, China has begun to export its own globalisation to other countries. On 24 October 2014 China invited participation in a new international Asia Infrastructure Investment Bank (亚投行 [yà tóu háng]) which so far the US and Japan have declined to join: https://www.aiib.org/en/aboutaiib/governance/members-of-bank/index.html (accessed 30.01.2019). In 2013 President Xi Jinping had announced his 'Belt and Road' initiative to provide infrastructure investment in countries strung along the historic overland 'Silk Road' and a new 21 st century 'maritime Silk Road' and beyond. https://www.chathamhouse.org/expert/comment/belt-and-road-not-completely-closed-shop (accessed 26.1.2019). 
Suddaby and Muzio (2015) expound recent formulations of the 'ecological-institutional' theory of organizational change as a helpful lens through which to analyse the transnational regulation of professional services. As an example, Mennicken (2008), in analysing the use and circulation of international auditing standards [ISAs] in post-Soviet Russia, replacing the traditional state audit mentality and procedures 'as it faces up to the challenges of international harmonisation', draws on inter alia Latour (2005) and other proponents of 'actor-network theory' (ANT) 23 that focus on the networked interrelations of the various actors and other factors ('actants') involved in the development and conceptualisation of fields and arenas of institutional activity that comprise ever-changing 'linked ecologies'.

Appendix II here emphasizes some important differences from Russia in China's political, social and economic contexts. One can nevertheless draw on Mennicken's (2010) framework of linked ecologies to explore the particular characteristics of the Chinese institutional history and what may be the implications for the future international role of its still rapidly expanding firms. As Mennicken explains (p.335), 'following Abbott (2005, p. 248), "linked ecologies" have to be understood "in terms of interactions between multiple elements that are neither fully constrained nor fully independent."...'A linked ecologies approach emphasises change, internal dynamics and the overlapping and interpenetrating of previously distinct worlds. Rather than focusing on the ways in which different arenas, networks or fields give rise to the emergence of a particular accounting technology...attention is focused on the ways in which arenas and fields themselves come to be interlinked and reworked. Emphasis is placed on the modes and processes of mediation and co-production between different arenas or fields.'...(p.356): '[thereby] to make more room for the complexities and paradoxes that derive from attempts to spread and utilise somewhat ambiguous and ill-defined Western concepts of market-oriented auditing.'

${ }^{23}$ Ezzamel \& Xiao (2015) also deploy ANT in their analysis of the changing interpretations of 'Chinese characteristics' (c.f. Macve, 2020). 
An ecology is characterised by 'its set of actors, its set of locations and the relation it involves between these' (Abbott, 2005, p. 245). According to Abbott, the particular social structures and locations of an ecology are not pre-existing positions: 'It is the process of constructing the relations between actors and locations that in fact constitutes and delimits both actors and locations. Analytically and empirically, the relational process is prior' (Abbott, 2005, p. 248). A linked ecologies approach thus underscores that audit and markets, and the boundaries that come to be formed around them, only exist in relation to other arenas of economic, political and social activity.

One must therefore explore how significant institutional roles and their (self)conceptualizations among China's auditing firms have been changing alongside their changing connections - both within China and in their international linkages - within a changing constellation of linked actors and forces. What is clear is how the State, i.e. the Chinese government controlled by the CPC, continues as the most significant actor both within China and also in its framing of Chinese institutions' international relations (e.g. Hughes, 2016).

As Macve (2020) deploys it: 'Neo-institutional theory seeks to link changes in culture and beliefs, in institutions, in organizations, and in individuals' discourses and practices (e.g. Lounsbury and Zhao, 2013). Suddaby and Muzio (2015) trace the development, building on Abbott $(1988 ; 2005)$, of a general "ecological-institutional" theory of organizational change as a helpful lens through which to analyse the transnational growth and regulation of IPSFs. On the partial analogy of biological ecosystems and their subsystems and how their internal and external linkages co-evolve (competitively or symbiotically; tending to equilibria or disequilibria) the theory focuses on the professions as subsystems of institutional ecosystems and on their co-evolving internal and external linkages (but differing from biological evolution in recognising human agency throughout)..... 
'As Suddaby and Muzio (2015, p.39) summarize, one is looking at how far the processes of institutional work result in stability or disequilibrium, and in an environment of competition or symbiosis with other institutions, to attempt "to understand the dynamic interaction between professions and other social institutions and how these mutually inform, reinforce, and complement each other"....

'[T]his study therefore explores how significant institutional roles and their (self)conceptualizations among China's newly created auditing professionals and their firms have been rapidly changing and interacting with their changing connections - both within China and in their international linkages - with a changing constellation of linked actors and forces....[T]hese "linked ecologies" include most importantly the State, i.e. the Chinese government controlled by the CPC, which continues as the most significant actor both within China and in developing China's international roles. Within China it directs accounting and auditing development and shapes its changing interactions with other arenas and fields, primarily through its direction of higher education and through the (sometimes conflicting) mediation of MoF, CSRC and CICPA and their vigorous promotion of mergers and "localization" of audit firms, of development of these firms' NAS skills, and of their convergence with IFRS and IAS, alongside the enhancement of corporate governance practices in their client companies.

'Internationally it frames Chinese accounting institutions' international relations, especially through increased influence within IASB and IAASB and its promotion of integration with Hong Kong's profession and stock market. Its relations with overseas professional accounting bodies, together with its encouragement to CICPA firms to integrate with international professional networks of audit firms overseas, complement its encouragement and support of the expansion of Chinese overseas investment (for example recently through the "Belt and Road" initiative) and of strengthening China's wider global 
influence in an increasing variety of arenas. In turn these emerging linkages and influences have served to shape and reshape the government's own agendas.

'However, one must also recognise....continuing potential barriers to integration within the prevailing neo-liberal world order and its institutions, resulting from the underlying "Chinese characteristics" of a culture of control and guānxì, alongside the continuing strength of the different incentive structures around and within the domestic SOEs in the economy (e.g. Wang et al., 2008) and some growing political antipathy to "Western values". There are also complex interrelationships between different organs of the State including the relative spheres of the central and provincial governments, and of a range of ministries, as well as of the "rule of law" that is exercised primarily as an administrative arena of the government and Party.24 On the other hand, the growth of the Chinese economy has been so rapid over the last 40 years of the "reform and open" policy that there have been accompanying intergenerational transformations in education levels and cultural values that will continue to shape and reshape successive generations' orientation to and influence on China's international roles. 25

'As well as the Chinese State there are other significant market and regulatory arenas with which China's accounting developments have been rapidly co-evolving, including the huge stockmarkets in Shanghai, Shenzhen and Hong Kong; the increasing presence of the international networks of auditing and accounting firms and their educational and training provision to China's new auditors (e.g. Stuttard, 2009); the import of international accounting and auditing standards alongside Western models of professional bodies; and the impact from cross-listings of Chinese companies on overseas stock exchanges (especially in the US)

24 Brandt et al. (2014) point out that under the Emperors, as now, the dispensation of law was primarily a responsibility of the administration (central and/or local), rather than of an independent judiciary so there is a different understanding of what is meant by the 'rule of law' (e.g. Feuchtwang \& Steinmüller (2017), Chapter 16). However, one of our most senior UK interviewees commented that the settlement of commercial disputes nowadays through arbitration is very efficient. ${ }_{25}$ See e.g. Brandt et al. (2014) and Feuchtwang \& Steinmüller (2017) for comprehensive reviews of recent developments in China and their historical economic, political and cultural roots. 
following IPOs both of giant SOEs (especially banks and energy companies) and of private start-ups (especially new technology companies) with resulting interactions with overseas national regulators. China's development of its auditing profession has also brought about changes in these arenas as well as being influenced by them. This study therefore necessarily sets out to open up a range of "linked ecologies", national and international, and the interactions between them as a basis for more specifically focussed questions for future research.

'Probably the outstanding feature of the Chinese environment is the remarkable speed with which these changes have taken — and are still taking — place. Within this interactive framework the study seeks to deconstruct the political and academic rhetoric that adopts the anachronistic dichotomies of continuing to label the accounting and auditing firms as "foreign / Chinese", or as "Big 4 / the rest", and to relate the changes in these Chinese institutions to world-wide changes in the "connecting worlds" of IPSFs (e.g. Suddaby et al., 2007; Empson et al., 2015).'

As described in Macve (2020), China may be seen (in this as in other arenas) as having played 'a long game' in which there have been broadly three stages of development:26 first, from 1978 laying the foundations by bringing in foreign expertise; second from 1995 building a unified profession and developing the capability to challenge foreign competitors; third (and currently) turning the foreign competitors into 'Chinese' firms. Outside North America and the EU the Big 4 may still be regarded as 'foreign firms',27 but this strategy has

\footnotetext{
${ }^{26}$ Ramirez (2010) traces a similar trajectory in France. Samsonova-Taddei \& Humphrey (2014: 918-19) highlight the first two of these stages in China but do not explore the third and its potential consequences for the traditional stereotyping of firms. Gillis (2014a) only briefly considers its implications in his concluding chapter as does Gillis (2014b) but does not explain how it fits with his 'Gramscian' analysis of the Big 4's 'hegemony' 27 And within the EU before the UK's entry to the Common Market in 1973. (Our analysis does not consider any possible global consequences of the UK leaving the EU on 31st January 2020.)
} 
broadly matched the ambitions of the UK-American firms themselves, especially the Big 4. 28 Indeed, their strategy worldwide has generally been to establish a presence that is initially managed by expatriates (who are expensive to maintain and compensate), but with the longer-term aim of 'naturalizing' / 'localizing' the firm to be run by local nationals, a process which would normally require some 20-30 years or more of building up sufficient numbers of sufficiently experienced local partners who, as far as possible, have acquired sufficient 'tacit' knowledge and internalized the firm's culture (e.g. Faulconbridge, 2015: 428-9).

Key events included the entry into China from 1995 onwards of the 2nd-tier international networks; China joining the WTO in 2001; the publication of the MoF/CICPA strategy in 'Document 56' in 2009;29 the 2011 grant of 'H-share' licenses to 11 firms (including the Big 4, the Chinese members of 2nd-tier international networks, and leading homegrown firms) to audit companies listed on the Hong Kong stock exchange; and the $2012 \mathrm{MoF} / \mathrm{CICPA}$ requirement for the Big 4 audit firms to 'localize', i.e. be managed by Chinese CPA partners30 (see e.g. Macve, 2020: Figure 1).

Throughout the MoF has seen professional status as a political issue and has been resolute in its promotion of CICPA's qualification.

\footnotetext{
28 During the period under review the set of the largest international firms has gone from the 'Big 6', to the 'Big 5' to the 'Big 4' (referred to in Chinese as 大四 [dà sì]). Like Suddaby et al. (2007) this paper generally uses this term even when the actual number was greater, unless the specific context requires a more exact usage. 29 The strategy in Document 56 comprised, first, aiming to establish a tiered structure of ' $10-200-7000$ ' firms, of which the largest 10 would be in a superleague of audit firms with multinational operations that could service large complex companies and potentially rival the worldwide international audit firms; second, extending the service range of audit firms to include various non-audit consulting services (NAS)); and third, improving the auditing environment (including the adoption of international accounting and auditing standards). For further discussion see Gillis (2014a); Macve (2020).

30 However Gillis (2014b) notes that even if the audit firm is 'localized' there may still be a firm above that in the international structure with a board or managing committee where Chinese CPAs still do not predominate.
} 


\section{The changing international context}

As Macve (2020) argues, 'Suddaby et al. 2007 have seen recent decades of changes in professional services firms — and in particular accounting firms — and their regulation as characterised by "shifting governance: from local monopoly to global cartel”( p. 337). But while this pattern identifies major changes that have emerged from the West31-and although China has joined the WTO and adopted international accounting and auditing standards, while its listed companies increasingly adopt Western patterns of corporate governance in line with the expansion of its stockmarkets - it is necessary to explore how closely this pattern fits a China whose "socialist market economy with Chinese characteristics" nevertheless remains outside the neoliberal "Washington consensus" version of capitalism. Its biggest companies and financial institutions, although partly listed domestically and overseas, are still state controlled; and bank finance (in turn primarily supplied by the giant state controlled banks) has been even more important than stockmarket finance (Allen et al. 2008) — with private finance by entrepreneurs and from their families and contacts having been even more significant.'

It is also clear that the professional body (CICPA) seems determined to maintain and strengthen a traditional domestic regulatory role over the profession-to include the full range of audit firms of all sizes - albeit with its own important differences from Western professional bodies, in particular its direction by MoF and, to some extent, its conflict with CSRC whose prime objective is to improve and enforce stockmarket discipline among listed companies and their auditors and which also inspects their work.

Moreover, like other professional bodies that seek to define the characteristics of a 'Chartered Accountant' or a 'CPA', CICPA increasingly faces the difficulty of presenting as

\footnotetext{
${ }^{31}$ However Quack \& Schüßler (2015) contest the universality of this analysis; and Samsonova-Taddei \& Humphrey (2015) comment on how the firms failed to secure an EU-wide resolution on the issue of auditor liability and 'the residing significance of the authority of the nation state in the European audit policy context'.
} 
equal in quality the whole range of practitioners, from the very small to the internationally huge, while also managing the inevitable conflicts resulting from their varying commercial interests and the extent to which they perceive they need (or no longer need) the professional body to underwrite their credentials (cf. Suddaby et al. 2009; Faulconbridge, 2015: 437). The strongest card CICPA has in play (in addition to the authority deriving from its MoF pedigree) is its tightening insistence on the requirement that auditors licensed in PRC must come under its regulatory jurisdiction through having qualified as Chinese CPAs under its examinations.

International accounting and auditing standards are in large part the product of, and help to define, the Big 4 international accounting firm (cf. Cooper \& Robson, 2006). But they now also provide the basis on which the Chinese government and CICPA can claim that their country's own qualified accountants have the technical expertise to rival those firms. China has gained badges of 'world citizenship' through its participation in WTO / IFAC / IASB etc. and is increasingly negotiating its own position vis a vis such bodies that set international standards. It has quickly learned the rules of the game as it gains membership of the relevant bodies, 32 and given its ever growing economic power, the development of its own 'soft power' may increasingly reshape the 'international regulatory field' (cf. Reich \& Lebow, 2014).33

\section{The Chinese profession today}

While China is widely perceived in the West as now essentially running a 'capitalist' economy — and indeed it participates internationally in Western capitalism's international avatars such as the WTO and convergence with international accounting and auditing

\footnotetext{
32 There has been a Chinese board member of IASB since 2007 http://archive.ifrs.org/Aboutus/IASB/Members/Pages/Members-of-the-IASB.aspx; https://www.ifrs.org/about-us/ourstructure/iasb/jianqiao-lu/ (accessed 29.1. 2019) and there are now a Chinese Trustee of the IFRS Foundation and Chinese members of the IFRS Advisory Council and of IAASB. See Macve (2020) Appendix II for further details.

${ }^{33}$ Note that even Western regulators face difficulties in their relationship with the dominant international bodies. For example the CEO of the UK's FRC has commented that 'working with the IASB is like pushing water uphill' (Accountancy Age 25.07.14: 'FRC reveals “struggle” in IASB discussions').
} 
standards, and it grants increasing discretion to large areas of the economy to undertake experiments with new economic arrangements-nevertheless the CPC's official designation remains that of 'a socialist market economy with Chinese characteristics' (e.g. Gewirtz, 2017) and China still maintains a largely top down, government controlled system of directing and implementing economic development. Central government and provincial government SOEs remain a significant sector of the economy.

In the centrally planned socialist economy under Chairman Mao SOEs were the centres for providing social welfare including housing, food and clothing rations, education, medical treatment and post-retirement benefits and there was underemployment rather than unemployment ('the iron rice bowl'). 34 The SOEs were also protected from bankruptcy. Unravelling this nexus of economic, social and political relationships and creating substitutes in the more mobile new economy has proved to be a gradual process leaving residual corporate governance problems in SOEs (e.g. Wong, 2014). Provincial governors (shěng zhăng [省长]) (who are always appointed from outside the province) have strong incentives for the SOEs under their own provincial government to be seen to do well as their own prospects for advancement to the central government have relied in large measure on how much their province's GDP increases. 35 The Chinese government has continued to pursue a policy of gradually relaxing controls over and privatising the remaining SOEs, 36 but more recently President Xi Jin Ping has signalled a return to consolidating their position where this is seen as being in the national interest.

Within this context the Chinese firms in the 2nd-tier international networks and the largest stand-alone firms have risen up the CICPA rankings to challenge, and begin to

34 http://www.pacificbridge.com/publication.asp?id=44 [accessed 4th Aug 2011]; Feuchtwang \& Steinmuller, 2017.

${ }^{35}$ For some US concerns about the continuing role of SOEs see e.g. http://www.heritage.org/research/testimony/2011/04/chinese-state-owned-enterprises-and-us-china-economicrelations (accessed 11th Jan 2012).

${ }^{36} \mathrm{http}: / /$ www.china.org.cn/wap/2014-07/16/content_32968137.htm （accessed 16 July 2014) 
overtake, the Big 4 in the domestic market, although the CSRC still prefers the Big 4 to be the auditors of the giant financial institutions that are cross-listed in the US in order to reinforce those instituions global credibility (see Appendix I).

\section{Alternative futures?}

I now attempt to highlight, from the complex web of relevant factors in the history, the key forces that may continue to shape the future.

The historical interrelationships of the stand-alone Chinese firms with the Big 4 and, more recently, with the second-tier international audit firm networks - and the ways in which the so-called 'foreign' Big 4 firms are themselves 'localizing' their Chinese firms which may create new opportunities for them, perhaps involving mergers within China-coupled with the Chinese government's drive for both the adoption of international accounting and auditing standards and for building an increasing role in shaping them, now problematize any clear notion of what is an 'indigenous Chinese' firm.37 However, favouring the view that the worldwide profession will become recognisably more 'Chinese' — as discussed in the interviews in mainland China, Hong Kong and the UK reported in Macve (2020) — are:

(1) The likelihood that the Chinese members of the Big 4 and the 2nd tier international networks will soon become their largest member firms (which may thereby come to lead their own international growth strategies);

(2) the international extension of 'Brand China' in other spheres (e.g. including now motor vehicles);38

(3) the strong direction and support given by the Chinese government to achieving this goal and its fostering of the expansion in complementary spheres in China to

37 See Macve (2020) for further discussion.

${ }^{38}$ The quality of cars is much more obvious and easier to compare than the quality of professional services, and especially of audit. The difficulties facing Chinese motor vehicle companies in marketing internationally is discussed in economia January 2014 (Issue 23) pp.58-9 (London, ICAEW). Although Great Wall Motors of China launched its SUVs (which have the largest share of the market in China, over 10\%) in the UK and elsewhere they have now been withdrawn http://greatwallmotor.co.uk (accessed 29.2.2020). However, the company that builds the iconic 'London black cabs' was rescued by a takeover by the Chinese automaker Geely of Hangzhou, which is also now the owner of Volvo http://www.levc.com/corporate/news/zhejianggeely-holding-group-/ (accessed 28.1.2020). 
compete with the West including:

(4) the formal adoption of international accounting and auditing standards, and

(5) the further extension of the scope and scale of the Shanghai Stock Exchange and of its links with the Hong Kong Exchange and potentially to other leading international exchanges (e.g. through the 'Stock Connect' initiative).39

(6) the increased adoption by listed Chinese companies of international corporate governance attitudes and apparatus and the increasing role of the financial press and social media in promoting transparency about them;

(7) the further expansion and strategic development of China's universities and their

business schools to compete in the World Rankings (alongside the vigour of its unique government-supported National Accounting Institutes);40 and

(8) the long familiarity with Western ways through the 'gateway' of Hong Kong.

It is therefore possible that before too long a recognizably 'Chinese' firm (or firms) may join the current Big 4 to become one of the new 'Big N'.41

However, the factors that may slow or ultimately hinder that global development include the remaining essential differences of China's economy and its 'Chinese characteristics' and in particular:

(1) the continuing (albeit very gradually reducing) economic significance of the government controlled SOEs, both the national 'giants' and their provincial counterparts;

(2) the as yet limited development of civil liability exposure for audit failure (as compared with the threat of government penalties) and the related difficulties of building international brand recognition while avoiding the risks of exposure to

39 http://www.goldmansachs.com/our-thinking/pages/stockhttps://www.bloomberg.com/news/articles/2020-0103/china-denies-reports-of-shanghai-london-stock-connect-halt-connect/report.pdf (accessed 28.1.2020).

${ }^{40}$ Complementing its plans for accounting firms, on 5 November 2015 the Chinese State Council announced its 'plans to get six universities into the top universities in the world by 2020, with some of these institutions being ranked among the top 15 in the world by 2030.' https://internationaleducation.gov.au/News/LatestNews/Pages/China-sets-direction-for-world-class-universities.aspx (accessed 30.1.2019). Most of China's public universities operate under the authority of the Ministry of Education and local governments, and while academic decisions are generally the delegated responsibility of the President and the academic hierarchy, this responsibility is under the leadership of the Communist Party and there is also a Party secretary in each department / school. The Party's role has recently been reaffirmed:

http://www.scmp.com/news/china/article/1617637/communist-party-reaffirms-its-control-overuniversities?page=all [accessed 29.2.2020].

${ }^{41}$ As predicted at an academic conference in 2010 by a former UK managing partner of PwC and former President of ICAEW (see Macve, 2020, for further discussion). 
potentially much greater liability in other jurisdictions and their capital markets (including Hong Kong);

(3) the as yet limited development of skills in NAS and in IPO support among accounting firms outside the Big 4, the 2nd-tier networks and a few leading independent firms (while the Big 4 still dominate international IPOs anddespite the introduction of rotation requirements - the audits of the main SOEs and financial institutions);

(4) the recruitment and training difficulties in upgrading domestic workforce skills from the manufacturing arena to professional and services arenas as China's higher education system has had to be kick-started again during the last 40 years or so;

(5) possible cultural barriers to the 'translation' and full integration of international accounting and auditing standards such as unfamiliarity with the exercise of professional judgement versus the more 'box-ticking' mentality of the homegrown firms' origins in government accounting and audit (which may also reflect the institutional logic of a different Asian educational tradition more widely—e.g. Feuchtwang \& Steinmüller, 2017, pp.218-9);

(6) a tradition of building business opportunities through personal relationshipsguānxì (关系)—rather than through modern brand marketing;42

(7) a tendency to impose top-down central control both from government (in particular from MoF and CSRC) and within the structural organization and institutional logics of business and professional firms, whether inside China itself or in the operation of Chinese investment and business expansion overseas (further complicated by the rather different imperatives driving CICPA and CSRC with regard to audit regulation and development); and

(8) the corresponding difficulties of ensuring successful mergers of previously independent audit firms in order to build 'bigger and better' rivals to the existing large firms.

\footnotetext{
${ }^{42}$ As was also normal in e.g. the UK profession before the abolition of the restrictions on advertising in the 1980s: http://www.parliament.uk/documents/lords-committees/economic-affairs/auditors/auditorswe1.pdf (accessed 2.12.2014)
} 
This paper has traced the rapid growth from nothing of the Chinese accounting and auditing profession in the period since 1978 and how, since its establishment in its present form in 1995, the CICPA (under the guidance of MoF) has built its credibility through structural adjustments to encourage the growth of large firms and through enhancing the professional qualifications and skills of its practitioners and their status as formally compliant with international standards for accounting and auditing. In parallel the corporate governance of Chinese listed companies is also being strengthened. The Chinese profession now has increasing global influence not only because of the sheer scale of the Chinese economy and its continuing rapid growth worldwide but because of its direct input to international standard setting bodies including IASB and the IFRS Foundation alongside IAASB. In this regard the development of the profession matches China's growing influence in the wider range of international financial and political institutions. It seems likely that this growth will continue: only the speed of change remains unclear.

China provides a dramatic contrast to the countries normally studied under the heading of 'emerging economies'. While there is still widespread poverty, especially in the countryside, the country's economic power has been transformed in just 40 years and the Government's goal is to eliminate absolute poverty and create a 'moderately prosperous society' by 2020.43

Space has restricted the analysis here to a general overview which has been framed within the neo-institutional theory that has been developed to examine 'Western' developments and the impact of 'glocalization' (e.g. Suddaby et al., 2007; Suddaby and Muzio, 2015; Baskerville and Grossi, 2019), and has also been deployed in analysing Russia's transition economy (Mennicken, 2008; 2010). But this analysis has rejected attempts to apply a Gramscian lens (e.g. Yee, 2009; 2012; Gillis 2014a). However, the relevance of a

\footnotetext{
${ }^{43} \mathrm{http}: / / \mathrm{www} . c h i n a d a i l y . c o m . c n / a / 201803 / 16 /$ WS5aab21d6a3106e7dcc142020.html (accessed 29.1.2019).The speed of this successful growth has however had the side effect of dramatically increasing inequality between the wealthiest and the poorest (e.g. Knight, 2013).
} 
theroretical lens primarily focussed on Western neo-liberal economies may also be challenged and suggest a need for new theoretical development.

There is clearly scope for further studies of individual aspects of the outstanding success of the Chinese developments in greater depth, alongside examination of the potential implications for the worldwide international accounting and auditing profession, which mark China out from other studies that have looked at smaller countries' emerging economies and have generally 'catalogue[d] a litany of failed or disappointing accounting reforms in DCs in the face of globalisation' (Hopper et al., 2017). 
APPENDIX I Statistics on largest audit firms within China

Source: WIND Database 11.9.2017(http://www.wind.com.cn/en/aboutus.html )

\begin{tabular}{|c|c|c|c|c|c|c|}
\hline Rank & 2011 & 2012 & 2013 & 2014 & 2015 & 2016 \\
\hline 1 & $P w C$ & $P w C$ & $P w C$ & $P w C$ & $P w C$ & $P w C$ \\
\hline 2 & $E Y$ & $E Y$ & $E Y$ & $E Y$ & $E Y$ & $\mathrm{BDO}$ \\
\hline 3 & Deloitte & Deloitte & KPMG & $\mathrm{BDO}$ & $\mathrm{BDO}$ & $E Y$ \\
\hline 4 & BDO & BDO & BDO & $K P M G$ & Rui Hua & Rui Hua \\
\hline 5 & KPMG & Pan-China & Rui Hua & Rui Hua & KPMG & Pan-China \\
\hline 6 & Pan-China & Yue Hua & Pan-China & Pan-China & Pan-China & $K P M G$ \\
\hline 7 & Yue Hua & $K P M G$ & Deloitte & Deloitte & Deloitte & Deloitte \\
\hline 8 & ShineWing & ShineWing & ShineWing & GT & ShineWing & ShineWing \\
\hline 9 & Da Hua & GT & Da Hua & Da Hua & Da Hua & GT \\
\hline 10 & Zheng Xin & Da Hua & GT & ShineWing & GT & Da Hua \\
\hline
\end{tabular}

Note: BDO is short for BDO China Shu Lun Pan CPAs, Zheng Xin is short for Tian Jian Zheng Xin, and GT is short for Grant Thornton China. GT and Tian Jian Zheng Xin merged and created a new GT early in 2012. 


\section{Appendix II Contrasts between China and Russia}

The closest comparator to our Chinese case is Mennicken's $(2008,2010)$ examination of the transition from state inspection to 'audit business' in Russia and of the role of the Big 4 there. There are parallels in the history, as a London chairman of a regulatory board commented in interview:

When we started, countries like China, Russia, they wanted the international firms to come in and bring with them the know-how and the technology. I think that - I would say that the delight at having the firms there is now quite significantly tempered by a concern that [they are] firms whose culture, values, I suppose to a degree loyalties, are orientated towards the Anglo-American model...

In China too, the nature of 'translation' of international accounting and auditing standards of Western origin into the very different cultural context of today's 'socialist market economy' 44 with its own distinctive 'Chinese characteristics' necessarily involves its own unique 'reinterpretation' in both discourses and practices (cf. Djelic, 2004).

Mennicken (2008) in her study of a Russian audit firm notes (p.407) that 'by the end of 2003, most large Russian accounting firms had been integrated into international audit firm networks' (including those of PKF, BDO and Baker Tilly International). Joining and acquiring the network name they 'became part of the network's brand and, thereby, significantly enhanced [their] position within the international division of audit labour'. And she notes (p.388) 'the desire to belong to the "West", reported by [the audit firm studied] in its drive to adopt International Standards on Auditing (ISAs). She concludes by observing (p.409): 'The joining of the network had made it possible for [the firm studied], and the ISAs respectively, to continue to inhabit multiple contexts and audit cultures, old and new, local and global, Western and post-Soviet worlds of audit activity.... The "connecting" of worlds is the process of forming such multiple linkages, including the various detours and experiments that [the firm studied] had to undertake before it could finally stabilise its connections - at least for a while.'

While there are clear parallels here with China's transformation of its auditing profession, in the case of China the differences in scale and speed of expansion in economic strength (Harrison \& Ma, 2013) are such that the Chinese firms are likely quickly to become one of the largest firms, if not the largest firm, in these networks.

We can also point to important differences from Russia in the political, social and economic contexts and in the 'linked ecologies' within which Chinese auditing firms have

\footnotetext{
${ }^{44}$ shèhuizhǔyì shìchăng jīngjì [社会主义市场经济]
} 
and are developing and their 'connecting worlds'. First, Mennicken comments that Russia's professional organizations had not been very influential in its adoption of international accounting and auditing standards. She observes (2010: 348) that the professional accounting associations in Russia were formed to promote and defend auditors' business interests while audit licensing is done directly by its MoF. However in China it is the CICPA (albeit 'under the guidance of MoF') that has developed a comprehensive strategy for enhancing the quality of Chinese CPAs to rival global competitors as IPSFs.

Second, Russia had also not developed such strong stock exchanges as has China. The enormous domestic stock exchanges of both Shanghai and Shenzhen and their IPOs have created business opportunities for non-Big 4 firms, while there is now the opportunity to penetrate overseas markets via experience in Hong Kong and potentially to rival the Big 4 there. As Gillis (2014a p. 267) argues, for the Big 4 the gigantic overseas listings, in particular of SOEs and VIEs in the US, consolidated their predominant position in China while this major factor had not been an important part of Russia's transition and the Big 4 achieved relatively less dominance of the audit market there (Mennicken, 2010: 355). And as the Big 4 firms in China are now increasingly (and rapidly) 'localized' one or more of them may adopt the role of becoming a 'Chinese' audit firm that becomes a global leader.

Third, Russia's government has also played a more backstage role. By contrast, China's government, albeit retaining its Communist political ideology, has been proactive in promoting the institutions of its new 'socialist market economy with Chinese characteristics', evident both in its sponsorship of university accounting programmes alongside the creation of the 3 huge 'National Accounting Institutes' (Suzuki et al., 2007) and also through its influence on CICPA and via CSRC in promoting international accounting and auditing standards - which has now given it roles in contributing to rather than merely being a recipient of the programmes of the IASB and IAASB (see Macve, 2020, Appendix II:b). This has strengthened the ways in which markets have been created through and for auditing of the kind that Mennicken traces within the linked ecologies of Russian institutions and their interactions with the West—but here with 'Chinese characteristics.'

Moreover, there are the particular institutional legacies of China's long history (Brandt et al. 2014) and China's re-creation of its profession had to begin after a decade's deprivation of tertiary education and with a need to restore such education and training across the whole range of academic and professional fields. In Russia education was always respected and although the profession itself had likewise been in abeyance during the Soviet era even then 
the traditions of double-entry bookkeeping had been preserved (Bailey, 1990), unlike in Maoera China where they had been banned as 'capitalist tools' (Ezzamel et al., 2007; Tang, 2000). Again, Russia does not have an equivalent of Hong Kong. Familiarity with Western ideas and with the roles of capitalist enterprise and of stock-markets suggests Hong Kong may be a gateway through which Chinese firms — starting with their ' $H$ ' share licenses (see Macve, 2020, Appendix III) - may build their reputation outside mainland China. But the continuing differences within 'one country, two systems' 45 (e.g. in language, culture, and the financial and legal system) may also prove a barrier for another 27 years or so.

45 yīguó liăngzhì [二国两制] https://www.bloomberg.com/news/articles/2019-08-27/countdown-to-2047what-will-happen-to-hong-kong-quicktake (accessed 28.2.20) 


\section{Abbreviations}

ACCA Chartered Association of Certified Accountants (UK)

AICPA American Institute of Certified Public Accountants (US)

ASBE Accounting Standards for Business Enterprises (PRC)

CAS Chinese Accounting Standards

CASB Chinese Auditing Standards Board

CICA China Institute of Certified Auditors (merged into CICPA in 1995)

CICPA Chinese Institute of Certified Public Accountants

CNAO China's National Audit Office

CPC Communist Party of China

CSA Chinese Standards on Auditing

CSRC China Securities Regulatory Commission (reports to Premier of PRC)

DC Developing country

FDI Foreign Direct Investment

FRC Financial Reporting Council (Hong Kong / UK)

HKICPA Hong Kong Institute of Certified Public Accountants

IASB International Accounting Standards Board

IAASB International Auditing and Assurance Standards Board (IFAC)

IAS International Accounting Standards (IASB: being superseded by IFRS)

IFAC International Federation of Accountants

ICAEW Institute of Chartered Accountants in England and Wales

IFRS International Financial Reporting Standards (IASB).

IPO Initial Public (stockmarket) Offering

JV Joint venture

LLP Limited Liability Partnership

MoF Ministry of Finance (PRC)

NAS Non-audit services

PCAOB Public Company Accounting Oversight Board (US)

PRC People's Republic of China

SGP Special General Partnership [tèshū pǔtōng héhuǒ (特殊普通合伙)] (PRC)

SOE State-owned enterprise (national or provincial) (PRC)

VIE Variable Interest Entity (US)

WTO World Trade Organization 
Abbott, A. (1988). The System of Professions: An Essay on the Expert Division of Labour. Chicago: Chicago University Press.

Abbott, A. (2005). Linked ecologies: States and universities as environments for professions. Sociological Theory, 23(3), 245-274.

Allen, F., J. Qian, and M. Qian (2008). China's Financial System: Past, Present, and Future, in Brandt, L. and T. Rawski (eds) China's Great Economic Transformation. Cambridge University Press.

Annisette, M. (1999). Importing accounting: the case of Trinidad and Tobago. Accounting, Business and Financial History, 9(1): 103-133.

Annisette, M. (2000). Imperialism and the professions: the education and certification of accountants in Trinidad and Tobago. Accounting, Organizations and Society, 25: 631-659.

Bailey, D.T. (1990). Accounting in the shadow of Stalinism. Accounting, Organizations, and Society, 15(6): 513-25.

Ballas, A.A. (1998). The creation of the auditing profession in Greece. Accounting, Organizations and Society, 23(8), 715-736.

Baskerville, R. and Grossi, G. (2019). Glocalization of accounting standards: observations on neo-institutionalism of IPSAS. Public Money \& Management 39(2) (April):101-110.

Baskerville, R.F. and Hay, D. (2010). The Impact of Globalization on Professional Accounting Firms: Evidence from New Zealand. Accounting History, 15(3), 285-308.

Bickers, R. (2017). Out of China. How the Chinese Ended the Era of Western Domination. Harvard University Press.

Bourdieu, P. (2014). On the state, Cambridge: Polity Press.

Brandt, L., D. Ma, and T. Rawski (2014). From Divergence to Convergence: Re-evaluating the History Behind China's Economic Boom. Journal of Economic Literature 52(1): 45123.

Caramanis, C.V. (1999). International Accounting Firms Versus Indigenous Auditors: Intraprofessional Conflict in the Greek Auditing Profession 1990-1993. Critical Perspectives on Accounting 10(2), 153-196.

Caramanis, C.V. (2002). The interplay between professional groups, the state and supranational agents: Pax Americana in the age of 'globalisation'. Accounting, Organizations and Society 27(4-5), 379-408.

Caramanis, C.V. (2005). Rationalism, Charisma and Accounting Professionalization: Perspectives on the Intra-professional Conflict in Greece, 1993-2001. Accounting, Organizations and Society, 30(3), 195-221.

Chua, W.F. and Poullaos, C. (2002). The Empire Strikes Back? An exploration of centreperiphery interaction between the ICAEW and accounting associations in the selfgoverning colonies of Australia, Canada and South Africa, 1880-1907. Accounting, Organizations and Society, 27(4-5), 409-445.

Cooper, D. J., Greenwood, R., Hinings, C., and Brown, J. L. (1998). Globalization and nationalism in a multinational accounting firm: The case of opening new markets in Eastern Europe. Accounting, Organizations and Society, 23(5/6), 531-548.

Cooper, D. J., and K. Robson (2006). Accounting, professions and regulation: Locating the sites of professionalization. Accounting, Organizations and Society 31(4-5): 415-444.

Crawford, A., S. A. Humphries \& M. M. Geddy (2015). McDonald's: A Case Study in Glocalization. Journal of Global Business Issues, 9(1), 11-18.

De Beelde, I. (2002). Creating a profession 'out of nothing'? The case of the Belgian auditing profession. Accounting, Organizations and Society 27(4/5): 447-470.

De Beelde, I., Gonthier-Besacier, N. and Mikol, A. (2009). Internationalizing the French Auditing Profession. Accounting Historians Journal, Vol. XXXVI, 1 (June): 29-60. 
Djelic, M. (2004) Social networks and country-to-country transfer: dense and weak ties in the diffusion of knowledge. Socio-Economic Review, 2, 341-370.

Empson, L., D. Muzio, J. Broschak, and B. Hinings (2015). The Oxford Handbook of Professional Service Firms. OUP.

Ezzamel, M., Spence, C., and Zhu, J. (2020) Thinking Like the State: Doxa and Symbolic Power in the Accounting Field in China. Cardiff Business School working paper.

Ezzamel, M., and J.Z. Xiao (2015). The development of accounting regulations for foreign invested firms in China: The role of Chinese characteristics. Accounting Organizations and Society 44: 60-84.

Ezzamel, M., J.Z. Xiao, and A. Pan (2007). Political ideology and accounting regulation in China. Accounting, Organizations and Society 32(7-8): 669-700.

Faulconbridge, J. (2015). Knowledge and Learning in Professional Service Firms. In Empson et al. (2015): 425-451.

Ferguson, C., Pinnuck, M. and Skinner, D.J. (2014). 'The Evolution of Audit Market Structure and the Emergence of the Big 4: Evidence from Australia.' Chicago Booth Research Paper No. 14-13 http://papers.ssrn.com/sol3/papers.cfm?abstract_id=2431727

Feuchtwang, S. and Steinmüller, H. (2017). China in Comparative Perspective. World Scientific Publishing Europe Ltd.

Gewirtz, J.B. (2017). Unlikely Partners: Chinese reformers, Western economists, and the making of global China. Cambridge, MA: Harvard University Press.

Gillis, P. L. (2014a). The Big Four and the Development of the Accounting Profession in China. Bingley, UK: Emerald.

Gillis, P. (2014b). China, the Big Four and a world of change. economia (January) 23: 68-9 (London, ICAEW).

Gramsci, A. (1935/1971). Selections from the Prison Network (Q. Hoare \& G. N. Smith, Trans.). London: Lawrence and Wishart.

Gwilliam, D., C-M. Teng, and O. Marnet (2014). How does joint provision of audit and nonaudit services affect audit quality and independence? A review. London: ICAEW.

Harrison, M. and Ma, D. (2013). Soaring Dragon, Stumbling Bear: China's Rise in a Comparative Context. The CAGE-Chatham House Series, no.6 (March). London: The Royal Institute of International Affairs.

Hopper, T., Tsamenyi, M., Uddin, S.,and Wickramasinghe, D. (2012) Accounting and Development, in Hopper,T., Tsamenyi, M., Uddin, S. ,and Wickramasinghe, D. eds (2012) Handbook of Accounting and Development, London: Edward Elgar, pp. 1-14.

Hopper, T., Lassou, P. and Soobaroyen, T. (2017). Globalisation, accounting and developing countries. Critical Perspectives on Accounting 43: 125-148.

Hughes, Christopher R. (2016). China as a leading state in the international system. In: Tsang, Steve and Men, Honghua, (eds.) China in the Xi Jinping Era. The Nottingham China Policy Institute Series. Palgrave Macmillan, London, UK. ISBN 9783319295480.

Karube, M. and Fukukawa, H. (2013). 'Integrating Personal Expertise: A History of Japanese Audit Firms, 1965-2010'. Institute of Innovation Research, Hitotsubashi University working paper \#13-07: http://econpapers.repec.org/paper/hitiirwps/13-07.htm .

Knight, J. (2013). Inequality in China : an overview. Policy Research working paper no. WPS 6482. Washington, DC: World Bank. http://documents.worldbank.org/curated/en/637401468025224192/Inequality-in-China-anoverview

Latour, B. (2005). Reassembling the social. An introduction to actor-network theory. Oxford University Press.

Lewis, T. (2005). In Partnership. KPMG's 60 Years in Hong Kong and 20 Years in China. KPMG [ASIN: B004QY0754]. 
Li, Jinhua (ed.) (2007). History of Audit in China, Vol. III (B) Chapter 6. Beijing: Foreign Languages Press.

Liu, Zhi Yu (1993). Economic Reforms and the Accounting and Auditing Profession in P.R. China: a Comparative History and Critique for Future Development. PhD thesis. University of Wales, Aberystwyth (March).

Lounsbury, M. and Zhao, E.Y. (2013) Neo-Institutional Theory. Oxford Bibliographies. DOI: 10.1093/OBO/9780199846740-0053 (accessed 3.6. 2019).

Luk, H. (2010), ShineWing: Blazing the Trail, A PLUS (the journal of HKICPA), 6(8) (August): http://app1.hkicpa.org.hk/APLUS/1008/APLUS1008_20-24_ShineWing.pdf (accessed 30.1.2019).

Macve, R.H. (1997). Discussant's comments on Caramanis, C.V. 'International Accounting Firms Versus Indigenous Auditors: Intra-professional Conflict in the Greek Auditing Profession 1990-1996' at Fifth IPA Conference, Manchester, 7-9 July 1997.

Macve, R.H. (2002). Insights to be gained from the study of ancient accounting history: some reflections on the new edition of Finley's The Ancient Economy, European Accounting Review, 11(2), 453-471.

Macve, R.H. (2020). Perspectives from mainland China, Hong Kong and the UK on the Development of China's Auditing Firms: Implications and a Research Agenda. Accounting and Business Research (forthcoming).

Macve, R.H. and Z-Y. Liu (1995). A Proposal to Form a Unified Chinese Public Accountancy Profession: An Academic Perspective. International Journal of Accounting 30: 48-61.

Mennicken, A.M. (2008). Connecting worlds: The translation of international auditing standards into post-Soviet audit practice, Accounting, Organizations and Society, 33 (4/5): 384-414.

Mennicken, A.M. (2010). From inspection to auditing: Audit and markets as linked ecologies. Accounting, Organizations and Society, 35(3), 334-359.

Pei, Minxin (2016). China's Crony Capitalism: the dynamics of regime decay. Harvard University Press.

Quack, S. and E. Schüßler (2015). Dynamics of Regulation of Professional Service Firms: National and Transnational Developments. In Empson et al. (2015): 48-70.

Ramirez, C. (2010), 'Promoting transnational professionalism: Forays of the 'Big Firm' accounting community into France', in Transnational communities. Shaping Global Economic Governance, S. Quack, M- L. Djelic (eds), Cambridge University Press, 2010: 271-302.

Reich, S. and R.N. Lebow (2014). Good-bye Hegemony! Power and Influence in the Global System. Princeton University Press.

Richardson, A.J. (1989). Corporatism and Intra-Professional Hegemony: A Study of Regulation and Internal Social Order. Accounting Organizations and Societv 14(5/6): 415431.

Samsonova, A. (2009). Local sites of globalisation: A look at the development of a legislative framework for auditing in Russia. Critical Perspectives on Accounting 20 (2009) 528-552.

Samsonova-Taddei, A. and Humphrey, C. (2014). Transnationalism and the transforming roles of professional accounting bodies: towards a research agenda. Accounting, Auditing \& Accountability Journal, 27(6), 903-932.

Samsonova-Taddei, A. and C. Humphrey (2015). Risk and the construction of a European audit policy agenda: The case of auditor liability. Accounting, Organizations and Society 41(C): 55-72.

Stuttard, Sir John (2009). A History of the International Accounting Firms (or more properly of Coopers \& Lybrand and PwC) in China from 1979 to 1999 [provided by the author]. 
Suddaby, R., D. J. Cooper, and R. Greenwood (2007). Transnational regulation of professional services: Governance dynamics of field level organizational change. Accounting, Organizations and Society 32: 333-362.

Suddaby, R., Y. Gendron, and H. Lam (2009). The Organizational Context of Professionalism in Accounting. Accounting, Organizations and Society 34(3-4):409-427.

Suddaby, R. and Muzio, D. (2015). Theoretical Perspectives on the Professions. In Empson et al. (2015), 25-39.

Suzuki, T., Y. Yan, and B.Y. Chen (2007). Accounting for Growth and Transformation of Chinese Businesses and Economy: Implications for Transitional and Development Economics. Socio-Economic Review 5: 665-694 [Oxford University Press]

Tang, Y.W. (2000). Bumpy road leading to internationalization: a review of accounting development in China. Accounting Horizons 14(1): 93-102.

Thornton, P., Ocasio, W., and Lounsbury, M. (2012). The Institutional Logics Perspective: A New Approach to Culture, Structure, and Process. London: Oxford University Press.

Wang, Q., Wong, T.J. and Xia, L. (2008). State ownership, the institutional environment, and auditor choice: Evidence from China. Journal of Accounting and Economics, 46(1), 112134.

Wong, T. J. (2014). Corporate Governance Research on Listed Firms in China: Institutions, Governance and Accountability. Foundations and Trends® in Accounting, 9(4), pp.259326.

Yee, H. (2009). The re-emergence of the public accounting profession in China: A hegemonic analysis. Critical Perspectives on Accounting 20: 71-92.

Yee, H. (2012). Analyzing the state-accounting profession dynamic: Some insights from the professionalization experience in China. Accounting, Organizations and Society 37(6): 426-444. 